\title{
Projeto Por Efeito: Fotografias de modelos físicos e a construção da imagem como concepção do projeto
}

\author{
Pedro Engel \\ Professor Adjunto, Departamento de Análise e Representação da Forma, Faculdade de Arquitetura e Urbanismo, Universidade Federal do Rio de \\ Janeiro (UFRJ). \\ Contato: pedroengel@fau.ufrj.br
}

\section{RESUMO}

Em diversos estúdios de escolas suíças de arquitetura, maquetes de grandes dimensôes são fotografadas do ponto de vista do observador e em condiçóes naturais de iluminação para gerar imagens que cativam o olhar por suas qualidades atmosféricas. As fotografias de modelos físicos empregadas atualmente no curso de arquitetura do Instituto Federal de Tecnologia de Zurique, a ETH Zurique, se inserem em uma tradição didática de mais de trinta anos que privilegia a imagem realista como meio para conhecer a arquitetura e pensar o projeto. Esta tradição está associada a um conjunto posturas que incluem a valorização da história como um repertório vivo de soluçóes, o apreço pela expressão visual da arquitetura e suas qualidades materiais e a busca pela produção de atmosferas significativas e adequadas a seu lugar e propósito. Este texto pretende discutir o papel das fotografias de modelos físicos enquanto dispositivos didáticos e pensar sua contribuição na articulação destes valores no ensino de projeto. Partindo de um estudo sobre práticas pedagógicas na cátedra Caruso, estúdio de projeto avançado da ETH Zurique, o artigo defende a hipótese de que isso é possível pela combinação de dois fatores: o controle das qualidades da imagem e o seu emprego como gerador primário da concepçáo.

Palavras-chave: Imagem; Ensino de Projeto; Fotografia; Modelos; Atmosferas

\section{ABSTRACT}

In a number of studios in Swiss architecture schools large-scale models are photographed in natural lighting conditions and simulating the observer's point of view in order to generate images that captivate the eye for its atmospheric qualities. The photos of physical models currently produced in the architectural course of the $\mathrm{Zu}$ rich Federal Institute of Technology, ETH Zurich, are part of a didactic tradition of more than thirty years that emphasizes the realistic image as a means to perceive and reflect on a project. This tradition is associated with a set of positions, which include regarding history as a living repertoire of solutions, valuing the visual expression of architecture and its material qualities and aspiring the production of atmospheres that are meaningful and appropriate to its place and purpose. This paper intends to discuss the role of photographs of physical models as didactic devices and discloses their contribution to the articulation of these values in design teaching. The article supports the hypothesis that this is possible by combining two factors: the control of image qualities and its use as the primary generator of conception. The arguments presented here are based on a study of pedagogical practices in the ETH Zurich and will be exemplified by the teaching methods in the advanced design studio held by the chair of Adam Caruso in 2013.

Key-words: Image; Architectural Design Teaching; Photography; Models; Atmospheres 


\section{Introdução}

Numa época em que renderings hiper-realistas e elaborados diagramas explicativos se tornaram corriqueiros em escolas de arquitetura, não deixa de ser curiosa a preferência por um modo aparentemente anacrônico para representar o projeto: fotografias de modelos físicos. Este método lento e oneroso é empregado em diversos estúdios de escolas suíças de arquitetura, onde maquetes de grandes dimensóes são fotografadas do ponto de vista do observador em condiçôes naturais de iluminação gerando imagens de notáveis qualidades atmosféricas que dão a impressão de retratarem edifícios já construídos. As imagens integram experiências pedagógicas das quais não são apenas o produto final, mas sim instrumentos de trabalho, participando do processo criativo desde as etapas iniciais e desempenhando a função de verdadeiras articuladoras do conhecimento arquitetônico.

A proposta deste texto é examinar as fotografias de modelos físicos em sua condição de dispositivos didáticos e, com isso, pensar sua contribuição para a efetivação de uma determinada agenda no ensino de projeto. A discussão se baseia em um estudo sobre práticas pedagógicas no Instituto Federal de Tecnologia de Zurique, a ETH-Zurique, as fotos de modelos integram uma tradição didática de mais de trinta anos que privilegia a imagem realista como meio para conhecer a arquitetura e pensar o projeto (BARAC, 2011). Examinaremos em especial a Cátedra de Adam Caruso, onde a opçáo por fotos de modelos aparece claramente associada ao compromisso com determinado conjunto de valores arquitetônicos profundamente arraigados na escola. $\mathrm{O}$ que se pretende demonstrar aqui é como as fotografias de modelos contribuem pra integrar estes valores na construção de posturas de projeto.
A hipótese a ser defendida é que este agenciamento depende da combinação de dois aspectos: um ligado às qualidades específicas das fotos de modelos como modo de representaçáo e outro ligado à sua posição no processo de concepção. Em primeiro lugar, é preciso compreender que este método de representação foi concebido para exibir aspectos valorizados na pedagogia dos estúdios e que propomos sintetizar em três tópicos: sua ligação com a cultura e história da arquitetura como um repositório vivo de soluçóes, a natureza material da arquitetura, sua capacidade de produzir atmosferas. As fotos de modelos, não apenas dar a ver estas qualidades, mas as registram enquanto efeito de uma realidade física, material. Assim, argumentaremos que há uma relação de causa e efeito que vincula modelos e imagens, tornando-as confiáveis para discutir arquitetura à luz dos valores preconizados pelos estúdios. Em segundo lugar, as fotografias de modelos estudadas neste trabalho são protagonistas nas etapas iniciais da concepçáo e exercem papel de destaque nas discussóes de projeto. Elas operam como sínteses prévias da concepção e, portanto, conferem aos efeitos visuais da arquitetura o papel de geradores do projeto. Daí a ideia de projeto por efeito e construção da imagem como concepção do projeto.

Para desenvolver esta argumentação proponho descrever os processos didáticos da Cátedra de Adam Caruso. Antes, contudo, é importante situar estes processos em seu contexto institucional e defini-los como parte de uma agenda pedagógica específica, mas alinhada com posturas arquitetônicas cultivadas ao longo de décadas na ETH Zurique.

\section{Ensino de Projeto com uma Agenda}

Como muitas escolas europeias, a ETH é organizada em unidades ${ }^{1}$, cátedras responsáveis por áreas específicas do saber arquitetônico. Atualmente são mais 
de trinta, das quais aproximadamente dois terços se dedicam ao ensino de projeto. Estas são coordenadas por arquitetos de reconhecida competência profissional e capacidade crítica. $\mathrm{Na}$ estrutura curricular, o ensino da concepção obedece a seguinte lógica: no primeiro ano todos estudantes frequentam a mesma cátedra de introdução ao projeto. No segundo, podem escolher entre três cátedras que trabalham com agendas muito similares, endereçando temas fundamentais da arquitetura. A intenção é garantir uma base sólida e comum a todos estudantes para que, a partir do terceiro ano, possam eleger entre uma ampla variedade de cátedras, incentivando-os assim a construir seu próprio percurso uma vez garantidas as competências básicas de projeto.

Tal arranjo também favorece, nas cátedras avançadas, a singularização das agendas de ensino, suscitando a explicitação de posturas e a nomeação dos princípios que guiam cada estúdio. Este alinhamento de posiçôes, entretanto, está inscrito dentro de um universo teórico comum, transversal à escola e aos escritórios de arquitetura. Segundo Irina Davidovici (2012) no ambiente da suíça-alemã o discurso teórico tem papel operativo, auxiliando os arquitetos em seu "esforço por justificar a forma” (p. 44). A escola possui um papel chave no exercício dessa lógica argumentativa, contribuindo para que o debate no departamento de arquitetura da ETH, com seu sistema de cátedras e alianças entre gerações, apresente uma recorrência temática que sugere a existência de uma espécie de sistema de valores subjacente na escola. (STEINMANN, 1991)

É neste contexto que combina singularização e continuidade teórica que a Cátedra de Adam Caruso se firmou como um dos estúdios de projeto mais profícuos da escola. Uma de suas marcas é justamente o uso sistemático das fotografias de modelos como padrão de representação. Distintos tipos de imagens, contudo, aparecem no ensino com papéis que vão da aproximação das referências arquitetônicas à apresentação e criação do projeto. Estes papéis estão interligados e corroboram para instituir uma abordagem de ensino e de projeto que Caruso descreveu como uma "busca pela imagem do projeto" (FLORIS e TEEDS, 2011). Trata-se de uma prática exercida no escritório, mas que foi cultivada também nas suas atividades pedagógicas.

O canadense Adam Caruso, formado na McGill em 1986, é sócio do inglês Peter St John no escritório Caruso St John Architects, sediado em Londres e Zurique. Segundo os arquitetos, conjugar as atividades profissionais com o ensino e a escrita lhes permite cultivar a reflexão acerca de sua postura como arquitetos. Entre os preceitos que orientam sua prática estão a busca por adequação e continuidade em relação ao contexto, o apreço pelas tradiçóes construtivas e pela solidez dos edifícios urbanos, a não submissão da forma ao programa e o declarado compromisso com referências arquitetônicas na concepção do projeto. Formados em meio à efervescência pós-moderna, Caruso e St John cultivam um apreço pela história da arquitetura como um amplo repositório de soluçóes que se estende muito além do movimento moderno.

Seus projetos aliam robustez e simplicidade espacial com uma curiosa predileçáo pela ornamentação e pelo uso de signos arquitetônicos recobrados das tradiçôes pré-modernas. A casca espessa dos edifícios se contrapóe à transparência moderna e possibilita separação nítida entre interior e exterior. Internamente costumam conceber espaços independentes, o que permite dotar os ambientes de caráter específico, condizentes com suas distintas dimensões e potencial uso (1997b). No exterior, sistemas de revestimento 
sofisticados costumam conjugar a expressão visual com a explicitação da materialidade.

A preocupaçáo com a concepção da imagem da arquitetura é evidente. Seguindo referências específicas a cada projeto, a imagem é sempre informada por elementos sedimentados na cultura arquitetônica e na arte do construir. As soluçóes construtivas são concebidas em função da imagem resultante, mas é o universo da construção que fornece elementos para conceber a imagem. Dito de outro modo, são os efeitos visuais que guiam a concepção e náo a performance técnica (1997b).

Estes preceitos aparecem em diversos textos dos quais Caruso é autor ${ }^{2}$ e ajudam a compreender as balizas da sua atividade pedagógica. Um artigo é de particular interesse para o propósito deste texto: o elucidativo Whatever Happened to Analogue Architecture (2009), onde Caruso

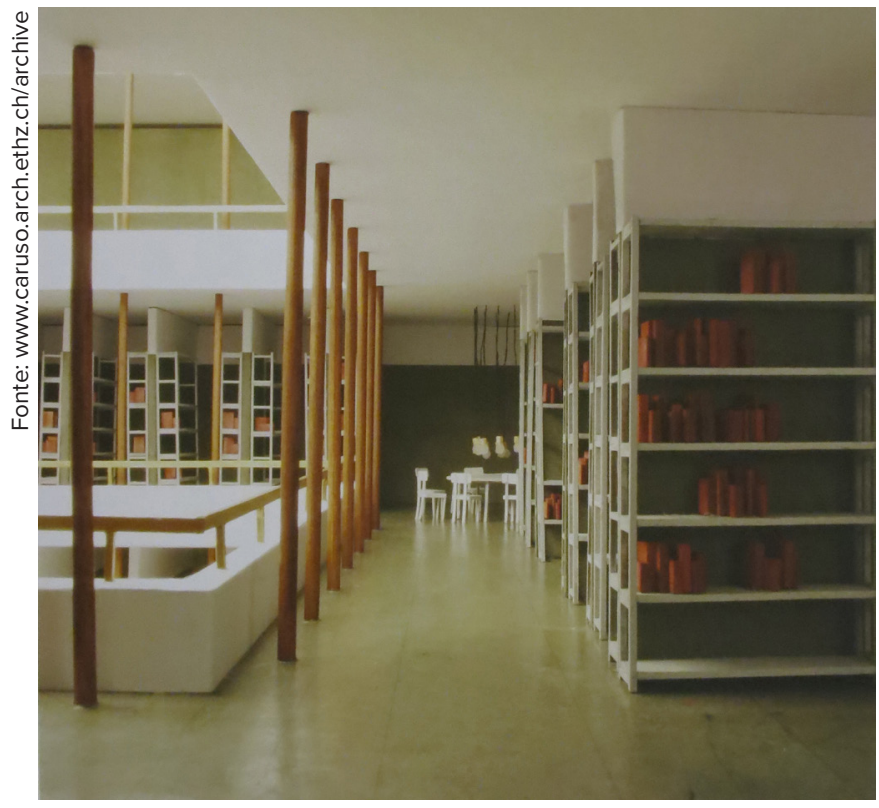

Figura 01: Fotografia de modelo físico. Projeto acadêmico da Cátedra Adam Caruso, ETH Zurique, semestre de primavera de 2013. Tema: Alles ist Umbau [Tudo é Remodelação / Reforma]. declara sua afinidade com as posturas cultivadas no estúdio de projeto Analoge Architektur, que teve forte influência na pedagogia da ETH Zurique nos anos 1980. O estúdio é frequentemente citado como um precedente fundamental do uso atual de fotografias de modelos. Uma breve digressão se faz necessária para compreender o processo histórico de consolidação destes valores arquitetônicos e sua relação com o uso da imagem como meio de conhecer e conceber a arquitetura.

\section{A imagem da arquitetura na pedagogia da ETH de Zurique}

A penetração da imagem na didática da ETH Zurique está vinculada à incorporação de preceitos associados a crítica do movimento moderno a partir da década de 1960. As narrativas que abordam o universo da ETH Zurique costumam destacar o impacto da passagem de Aldo Rossi pela escola nos

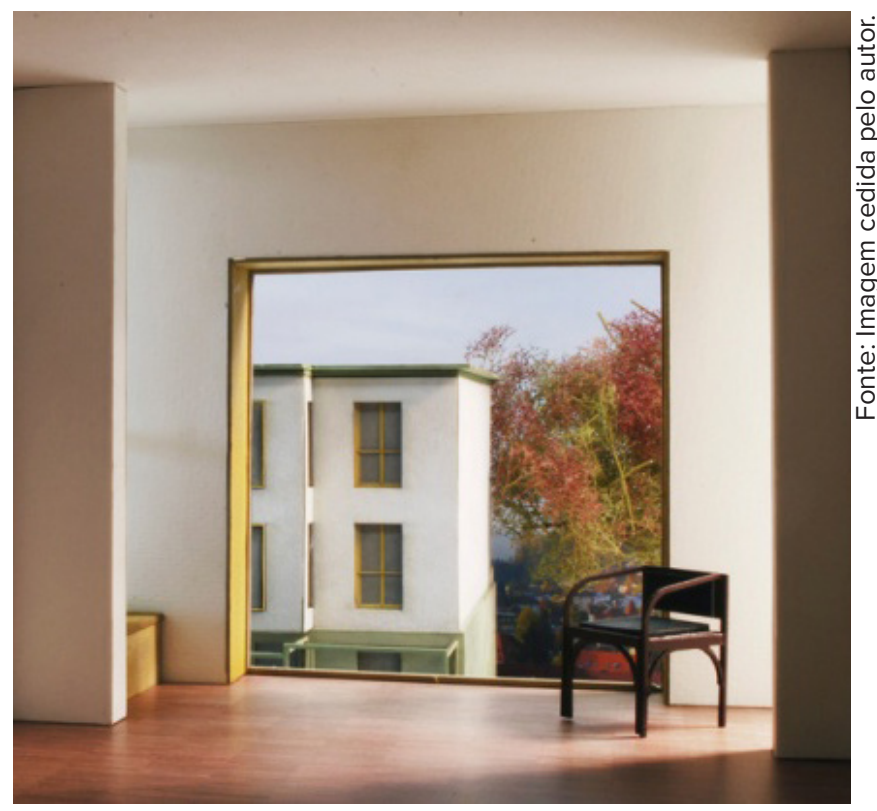

Figura 02: Fotografias de modelo físico da Cátedra Adam Caruso, ETH Zurique (alto). Semestre de primavera de 2014. Tema: Institution. 


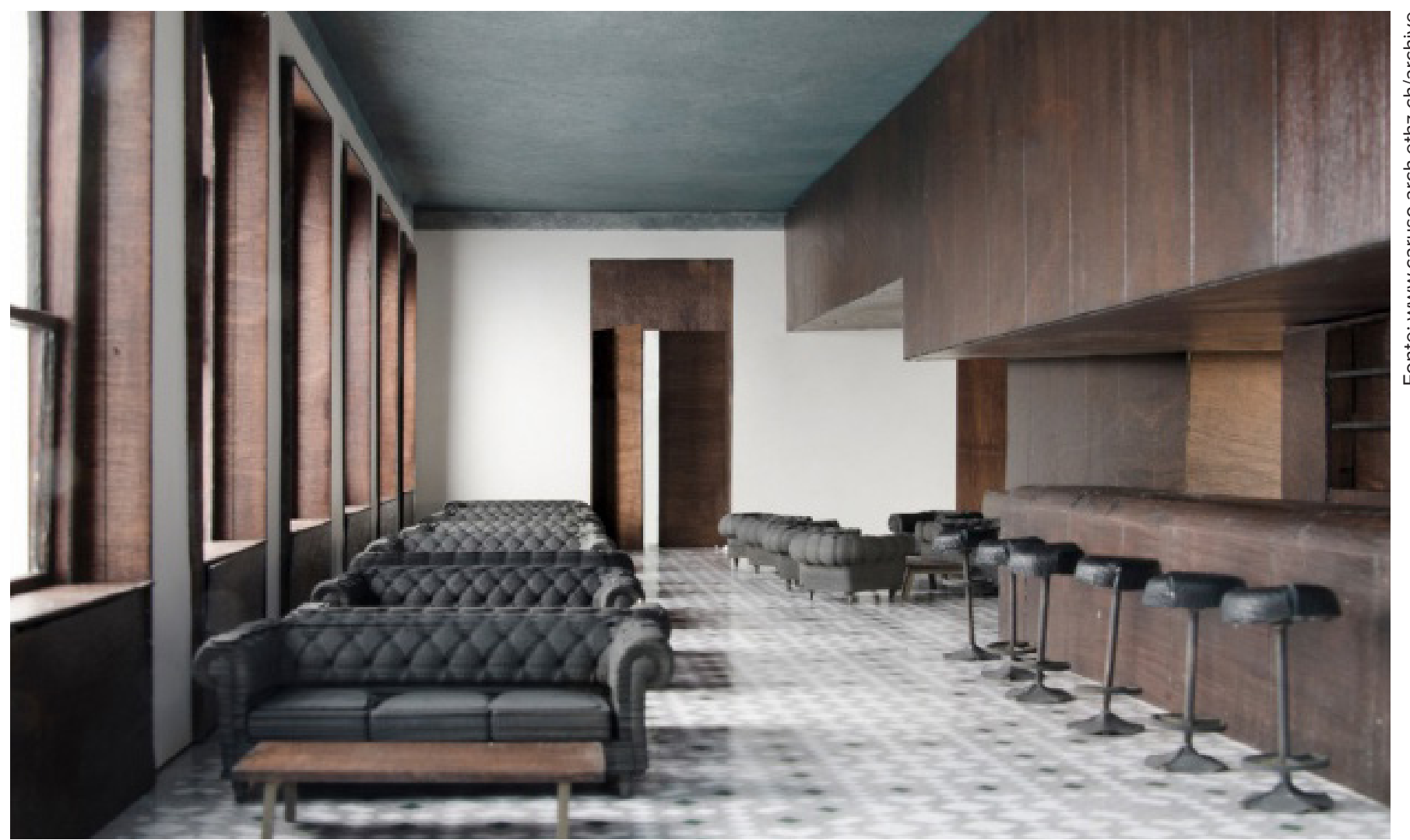

Figura 03: Fotografia de modelo físico. Projeto acadêmico da cátedra Adam Caruso, ETH Zurique, semestre de outono de 2012. Tema: Denkmal [Monumento].

anos 1970 , num ambiente marcado pela rejeição à tradição moderna, até então vigente e pela aparente dissolução da arquitetura em outras disciplinas (DAVIDOVICI, 2012; MORAVANSZKY, 2007). Rossi teria sido responsável por trazer os estudantes "de volta à prancheta", cativando-os com o discurso da autonomia e promovendo uma compreensão da arquitetura a partir de conceitos oriundo da sua própria tradição (STEINMANN, 1991, p. 95). O ensino no seu estúdio entre 1971-72 era baseado no livro Arquitetura da Cidade, de 1966, dando destaque à dimensão histórica e morfológica da cidade. Despertando o interesse dos estudantes pela tipologia, Rossi abriu caminho para a penetração do ideário norte italiano na escola, processo que se intensificou nos anos seguintes por meio de um grupo de professores do cantáo Ticino, porção italiana da Suíça.

Em pouco tempo os projetos na ETH passaram a ter seu lastro conceitual amparado pela explicitação das relaçóes contextuais e das referências históricas. A ideia de tradição passou a integrar o vocabulário da escola e não tardou para que os arquitetos da suíça-alemã buscassem se emancipar do universo italiano, definindo o que seria sua própria tradição arquitetônica a partir de referências locais. Este esforço envolveu uma revisão historiográfica, conduzindo tanto à recuperação de arquitetos situados até entáo "na periferia da história” (STEINMANN, 1989, p. 180), quanto fortalecimento de uma postura dita realista, interessada 
em arquiteturas ordinárias e anônimas, impulsionada pelo impacto de Aprendendo com Las Vegas.

Paralelamente, a incorporação da semiologia como perspectiva teórica para arquitetura abriu espaço para outra espécie de ligação com tradiçôes arquitetônicas regionais. Além da recuperação de conceitos preteridos pelo movimento moderno, como as noçôes de "caráter" e "adequação" - usadas para relacionar a aparência do edifício a seu propósito e sítio (STEINMANN, 1989) - a preocupação com a significação alimentou o interesse pela imagem da arquitetura. Para Martin Steinmann, crítico e historiador da arquitetura suíça, a noção de imagem foi central para tratar da significação da arquitetura, graças à capacidade da imagem de estabelecer conexão com outras imagens ou experiências (1989). A percepção visual da arquitetura passou, portanto, a ser entendida como um vetor de evocaçóes da memória pessoal e coletiva, e um meio de estabelecer relações contextuais e culturais mais profundas. (STEINMANN, 1982)

A importância conferida à imagem da arquitetura também ia ao encontro de uma mudança no discurso do próprio Rossi, que retornara à ETH Zurique para integrar um estúdio de desenho urbano entre 197879. Seu interesse pelas análises urbanas havia sido gradualmente preterido por uma perspectiva subjetivista para tratar da cultura arquitetônica. Em seu artigo de 1976, Uma Arquitetura Analógica, Rossi fala do seu interesse pelas relaçôes imprevistas estabelecidas pela memória, referindo-se a um universo "arcaico", "imaginado mesmo que silencioso" (p. 380). Segundo ele, sua abordagem de projeto dependia nesta época de uma coleção de objetos arquitetônicos, algo que descrevia como estando "entre o inventário e a memória”. A ideia de analogia promovida por Rossi forneceria um outro sentido à história, "concebida não somente como fato, mas como uma série de coisas, objetos afetivos a serem usados pela memória ou na concepção de um projeto" (1976, p. 380).

Essa inflexão teve desdobramentos na ETH com a formação do estúdio batizado de Analoge Architektur, conduzido entre 1983 e 1991 pelo professor Fabio Reinhart, colaborador no escritório de Rossi e seu auxiliar na primeira passagem pela escola. Articulado sobretudo pelo entáo assistente Miroslav Šik, o Analoge Architektur se tornou uma espécie de escola dentro da escola, rejeitando as entáo populares análises tipológicas de Rossi e adaptando a sensibilidade poética que movia suas analogias às condiçóes locais e ao espírito realista impulsionado pela leitura de Venturi e Scott-Brown. (CARUSO, 2009; STEINMANN, 1976)

A ideia de analogia adotada no estúdio correspondia ao procedimento de incorporar referências de projeto baseando-se em alusôes sutis, em versôes distorcidas ou adaptaçóes inventivas de alguns as-

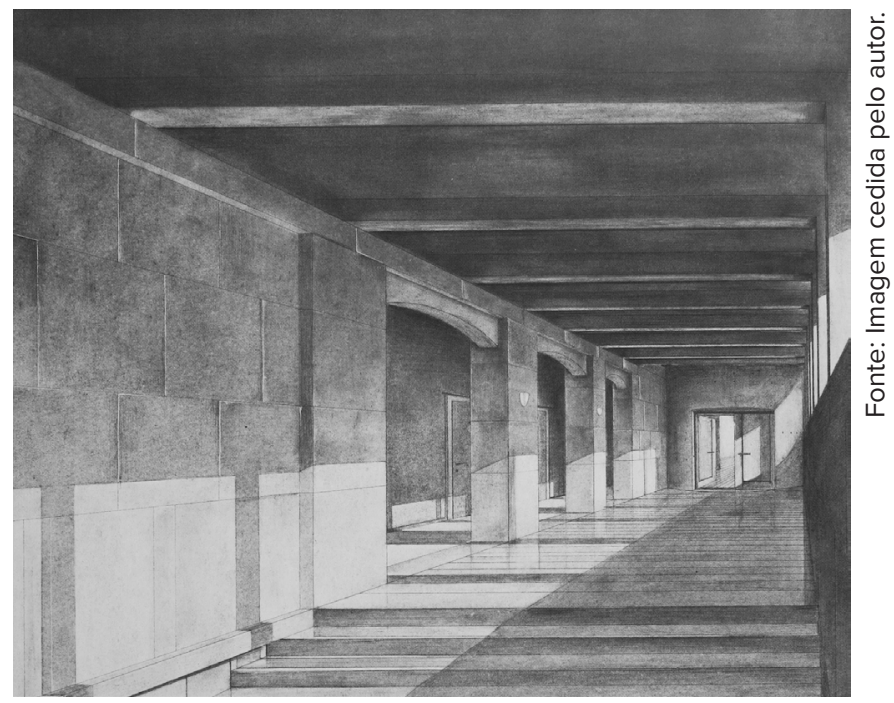

Figura 04: Projeto acadêmico do Analoge Architektur. Estudante Andreas Hild, 1985-86. Consulado da Alemanha em Zurique. 
pectos, se concentrando principalmente em qualidades acessíveis ao olhar: volumetria, materialidade, texturas, tratamentos formais, detalhes (LUCAN, 2001). O método implicava em trabalhar com amplo catálogo de referências que incluía arquiteturas relacionadas, de algum modo, com o universo cultural suíço-germânico.

As imagens eram essenciais no estúdio. Segundo Šik "o projeto iniciava e terminava como imagem" (2013, p. 45). Além do uso intenso de referências que serviam para dar partida ao projeto, uma das marcas notáveis do Analoge Architektur era o padrão de representação, protagonizado por desenhos monocromáticos em perspectiva com ponto de fuga, realizados com lapiseira e crayons em papel Canson, com linhas precisas com preenchimentos carregados. A busca pela objetividade era evidente na construção precisa dos desenhos e na exatidão do traço, garantindo um forte poder descritivo. Texturas, brilhos, reflexos e sombras explicitavam a realidade material pretendida para a edificação e contribuíam para dotar os desenhos de qualidades atmosféricas ( 1987; CARUSO, 2009). Os projetos eram inseridos em seu contexto, representado com o mesmo grau de detalhe do edifício. As cenas, contudo, eram desabitadas, como se o espaço estivesse em situação de espera. Assim como nas fotografias de modelos empregadas nas escolas suíças atualmente, todo o esforço de verossimilhança era concentrado em aspectos físicos e ambientais.

A qualidade das imagens permite inserir as práticas do Analoge Architektur em uma tendência mais ampla que instaurou gradualmente no cenário suíço alemão ao longo da década de 1980 e 1990, quando o termo "imagem" passou a ser empregado em associação ao termo "atmosfera" (STEINMANN, 1989). Ligada à noção de clima, a ideia de atmosfera é associada a estímulos que preenchem de modo contínuo e simultâneo o campo perceptivo, não necessariamente limitados à percepção visual (BÖHME, 1993). Em certa medida o apreço pela ideia de atmosferas entre os arquitetos suíços remete ao Rossi autor de Autobiografia Cientifica - livro publicado em 1981, mas preparado em parte durante sua estada na ETH Zurique. Nele o arquiteto relata vivências pessoais com a arquitetura repletas de descrições sinestésicas e contatos sensíveis com a arquitetura.

A noção de atmosfera também carregava um forte potencial simbólico, especialmente se considerarmos a preferência dos arquitetos suíços pelo uso do termo stimmung como alternativa ao sinônimo atmosphäre no idioma alemão.

Stimmung é uma expressão muito próxima da noçáo de atmosfera ou ambiência, mas se coloca de uma maneira mais precisa [...]. Em alemão 'stimmt' quer dizer: 'isto é adequado, justo' e 'stimmen' é o trabalho de afinar um instrumento, a busca pela harmonia entre os sons. Em arquitetura eu afino um espaço até que ele se torne adequado em relação a um determinado uso (MILLLER, 2013. p. 98).

Um ambiente dotado de stimmung é "afinado", apresenta uma espécie de sintonia interna, uma coerência harmônica entre os diversos estímulos que costuma também ser ajustada ao propósito daquele espaço. Não surpreende que o termo atmosfera tenha sido usado nos séculos XVIII e XIX como sinônimo de 
caráter, no sentido de caracterizar determinado ambiente e para torná-lo adequado ao uso e lugar. Nos anos 1990 emergiria a ideia de uma "arquitetura das atmosferas", formalmente mais abstrata e menos comprometida com referências históricas, que valorizava a materialidade e apostava na presença corporal buscando proporcionar experiências de exacerbada sensualidade subjetiva. Entretanto, mesmo na obra de arquitetos que foram referência desta postura, como Peter Zumthor, o potencial significativo das atmosferas seguiu sendo explorado, ainda que por uma via menos direta. (MORAVANSZKY, 2013)

Mesmo em meio ao interesse pelas atmosferas cabe notar que fotografias e desenhos verossímeis seguiram tendo um papel operativo, apensar de restritas ao universo da visualidade e mesmo considerando as óbvias limitações em relação à experiência direta. As imagens, enquanto representação, são ferramentas que, se observadas com a devida atenção, permitem aos arquitetos lidar com a expressão visual da arquitetura e suas atmosferas. Além disso, por serem reproduzíveis e armazenáveis, as imagens fotográficas se tornaram ferramentas-chave nos estúdios, permitindo construir - como no caso do Analoge Architektur - inventários e coleções com propósito didático.

Outro aspecto digno de nota acerca das limitaçôes das imagens, enquanto representações, é a sua relação com a arquitetura construída. Trata-se de uma questão delicada para os arquitetos suíços, especialmente após a segunda passagem de Rossi pela ETH, quando seus ex-alunos se deparavam com problemas efetivos da realização arquitetônica. Segundo Šik (2013) iniciou-se um debate sobre Rossi "enquanto um fabricante de imagens mais do que um arquite- to". Suas imagens eram consideradas magníficas, mas "logo que construídas, produziam edifícios cheios de erros de concepção e muito mal construídos” (p. 43). No sistema de valores compartilhado pelos arquitetos suíços o propósito de realizar uma boa construção se confunde com o próprio sentido da disciplina da arquitetura, também chamada de Baukunst - em alemão, arte da construção - e se reflete no modo que a arquitetura é concebida.

Acerca deste tema é importante mencionar o legado teórico de Gottfried Semper na ETH. Fundador da escola no século XIX e arquiteto de sua primeira sede, Semper defendia que a dimensão construtiva da arquitetura não se limita à eficácia técnica, mas deve ser pensada também a partir da dimensão expressiva e simbólica da construção, que se concretiza, poderíamos acrescentar, justamente enquanto imagem da arquitetura. Segundo Semper, o arquiteto deve possuir o domínio das técnicas para fazer o material desaparecer, dando lugar ao significado e à expressividade artística da superfície. (MALLGRAVE, 1989)

As afinidades com a postura defendida por Peter St John e Adam Caruso não são mera coincidência. Ambos declaram sua admiração pelas teorias semperianas, desprendendo notáveis esforços construtivos para gerar arquiteturas cuja elaborada expressão visual provém, em grande medida, do tratamento das superfícies. Também não é por acaso que desenhos do Analoge Architektur sejam identificadas como precedentes diretos das fotografias de modelos empregadas atualmente no estúdio coordenado por Caruso. O que as une, pode-se argumentar, é ambição de verossimilhança, a capacidade de exibir qualidades atmosféricas e dar a ver a fisicalidade e a expressão 
material da arquitetura, qualidades que também figuram nas imagens que costumavam integrar o processo de projeto de Adam Caruso e Peter St John.

\section{A imagens na prática de Caruso St John}

Modelos físicos realizados com o propósito de serem fotografados eram instrumentos corrente no processo de projeto de Caruso St John pelo menos até 2013, quando o escritório precisou aumentar sua produtividade. As imagens geradas por este método contribuíam para singularizar sua prática em meio à profusão de renderings digitais e diagramas. Além disso, eram verdadeiras ferramentas de projeto: os modelos integravam o processo de concepçáo permitindo visualizar as qualidades espaciais e lumínicas no interior do edifício. Com frequência os modelos eram realizados em foam-board, o que permitia sua modificação com relativa facilidade, as superfícies revestidas em papel com impressôes coloridas simulando materiais e texturas. Através das fotografias as miradas para o interior do modelo poderiam ser fixadas, comparadas e publicadas. Todo este aparato era, para Caruso, um meio de conduzir o processo de concepção como uma espécie de busca pela imagem do projeto:

Os modelos, e as fotografias dos modelos são uma maneira de chegar mais e mais perto de uma imagem que já existe nas nossas mentes, envolve articular todas essas qualidades naquela imagem. Eu aprecio o fato de que em um concurso se pode tentar comunicar o conceito e a atmosfera de um projeto em uma ou duas dessas imagens. Eu diria que a preocupação no escritório não é a produção do modelo, mas encontrar a imagem de um projeto. (Caruso em entrevista a FLORIS e TEEDS, 2011, pg.131)

Essa estratégia de concepção empregada no escritório alimentava também as práticas didáticas da dupla. Curiosamente, há relatos que indicam que os arquitetos foram responsáveis pela popularizaçáo da fotografia imersiva de modelos físicos no ambiente suíço. ${ }^{3} \mathrm{Em}$ 2001, Adam Caruso e Peter St John foram professores visitantes no atelier de Peter Zumthor na Academia de Arquitetura de Mendrísio (Escola de Arquitetura da Universidade da Suíça, no cantão Ticino). Conforme relata o ex-estudante Mihail Amariei (quando era professor assistente do Atelier Bearth em Mendrísio), foi nessa ocasião que eles introduziram na escola a prática de fotografar modelos e observar as imagens como meio de discutir o projeto.

Foi Adam Caruso e Peter St John que iniciaram o uso de fotografias aqui em Mendrísio quando foram professores convidados no atelier de Zumthor. Eu era estudante nesta ocasiáo. (...) Nós fazíamos os grandes modelos e os levávamos para o sol para fotografá-los contra o bosque, aqui atrás do edifício. As câmeras eram analógicas e nós tínhamos que revelar os filmes para saber se as imagens tinham dado certo, se haviam ficado em foco. Era bastante trabalhoso. As imagens tinham grande importância, talvez maior até do que os modelos. Elas permitiam acessar as atmosferas pois mostravam a luz natural no interior do projeto. Com o modelo você podia to- 
car no material, mover-se ao redor. Mas era com a fotografia que você imaginava como seria estar lá. (Entrevista com Mihail Amariei)

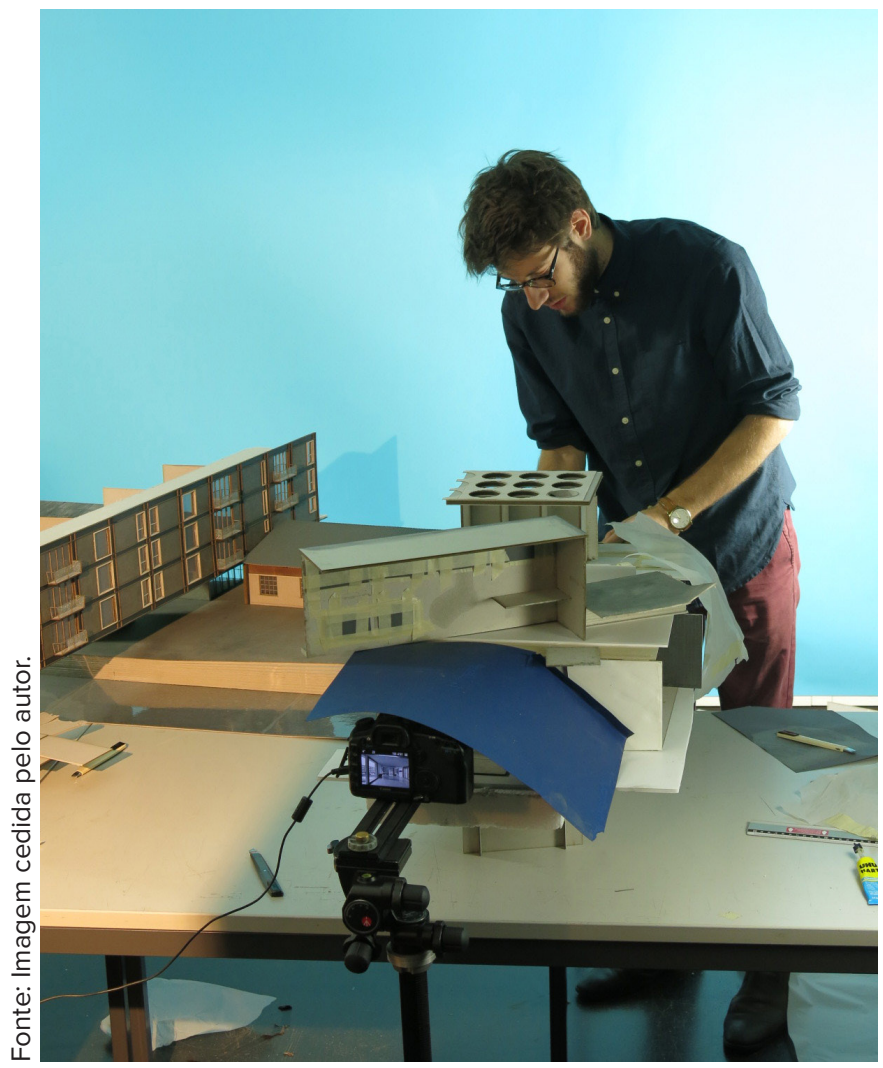

Figura 05: Estudantes da ETH Zurique durante a produção da entrega final do semestre de outono de 2013.

Anos mais tarde, na ETH de Zurique, Adam Caruso empregaria esta mesma estratégia com o auxílio de cortadoras a laser e câmeras digitais, permitindo o aprimoramento do método de representação. $\mathrm{O}$ relato de Amariei, contudo, aponta para aspectos importantes da natureza da fotografia de modelos enquanto modo de representação híbrido.

Os modelos físicos são considerados por muitos arquitetos um dos modos de representação mais confiáveis e diretos, pois compartilham com a arquitetura sua natureza material e espacial (DUNN, 2010). O registro fotográfico do modelo implica uma mudança de meio que oferece perdas e ganhos. A imagem fixa um ponto de vista, planifica a percepção espacial e oculta o que está fora do quadro. Por outro lado, possibilita o registro, o arquivamento e a publicação do projeto representado pelo modelo. No caso das fotografias imersivas, a câmera simula o olhar de quem penetra o espaço e, se ocultados os elementos fora da escala, permite gerar imagens de notável verossimilhança. (DERIU, 2012; SACHER2012)

O registro lumínico preciso é fator fundamental para o realismo destas representaçóes, mas a confiança na imagem fotográfica, não se deve apenas à sua verossimilhança. No célebre A Câmara Clara (1980, p. 74), Roland Barthes fala da "presença inalienável” do objeto fotografado na imagem, oriunda da conexão física existente entre o objeto e a câmera no momento da captura. Ainda que a manipulação digital tenha enfraquecido esta condição para as fotografias em geral, nos estúdios o ato de fotografar os modelos atesta a origem física e material das imagens, conferindo a elas certo valor de verdade, tornando-as confiáveis como meio de testar os efeitos visuais das decisóes de projeto.

As imagens, contudo, não são isentas. São condicionadas pelo aparelho fotográfico e atravessadas por convençóes culturais. As imagens abordadas neste estudo replicam clichês típicos da fotografia de arquitetura, mas talvez a referência mais relevante seja a "nova objetividade" da chamada "Escola de Düsseldorf de Fotografia", como é conhecido o grupo de fotógrafos artistas ex-alunos de Bernd e Hilla Becher. Entre os traços de suas imagens estão o distanciamento da câmera, a renúncia ao plano fechado, os enquadramentos centralizados, a frequente ausência 
de pessoas ou de açóes, a grande profundidade de campo focal, a luminosidade cristalina e as impressôes em grandes dimensôes. São procedimentos que favorecem o escrutínio atento, não das fotografias em si, mas dos objetos que elas retratam. São imagens cuja potência não parece vir da astúcia do fotógrafo, mas sim na força daquilo que ele quis colocar em frente aos nossos olhos. As fotografias de modelos empregadas no estúdio de Caruso, pode-se argumentar, ambicionam a condição ambígua de colocar o ponto de vista dentro do espaço, mas de prover suficiente distanciamento para que se possa escrutinar o ambiente considerando os aspectos arquitetônicos que contribuem para a produção das atmosferas e imagem da arquitetura.
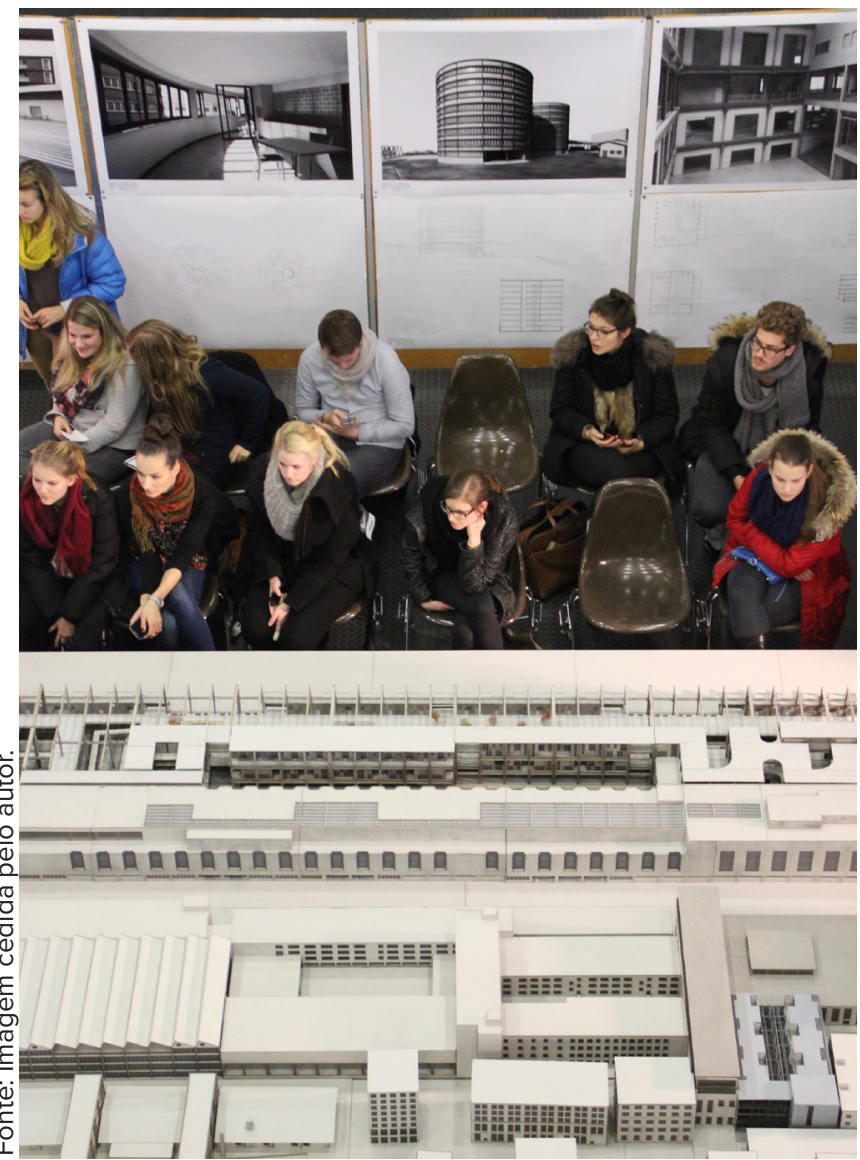

Figura 06: Apresentação de projetos do Atelier Christoph \& Gantenbein, ETH Zurique, semestre de outono de 2013.
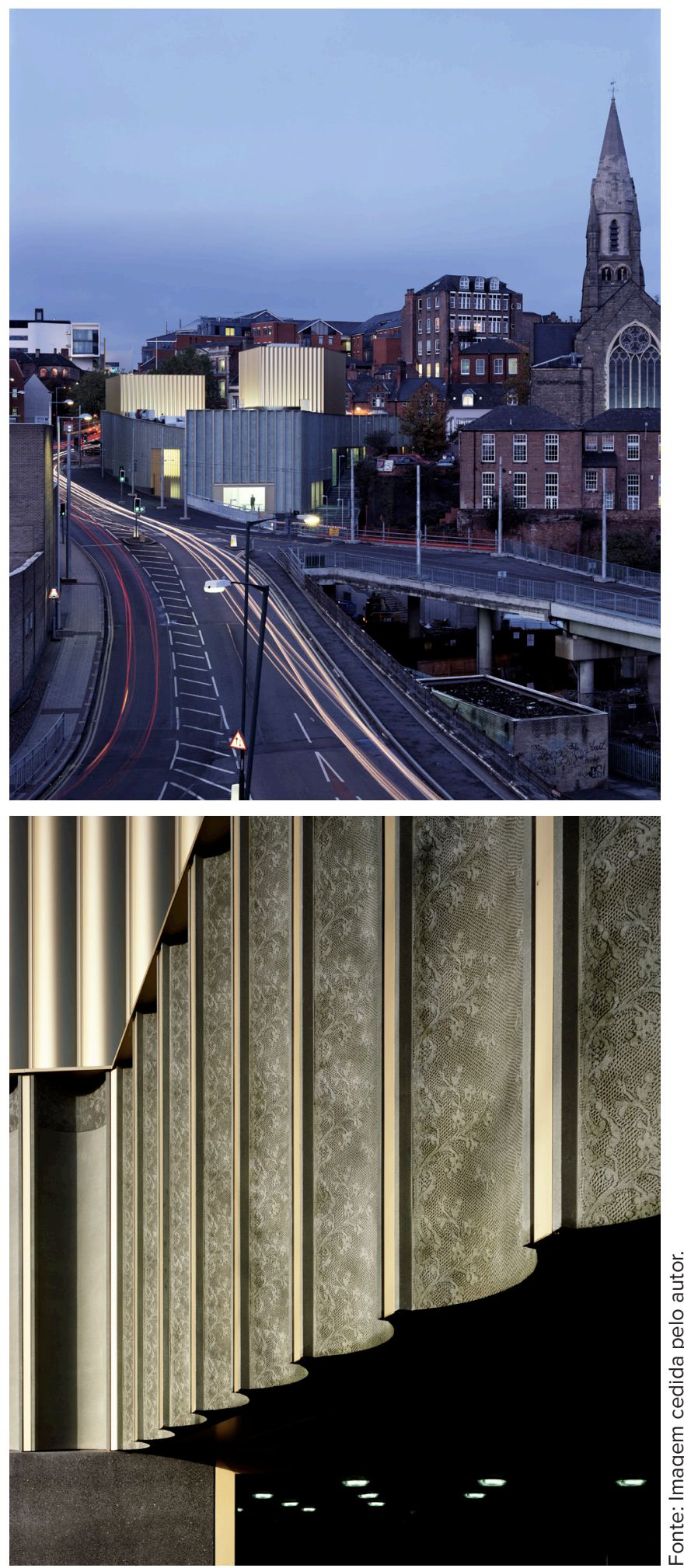

Figuras 07 e 08: Fotografias da Nottingham Contemporary Art Gaçerie, em Nottingham, Ingraterra, 2005. Projeto Caruso St John Architects.

Revista online do Departamento de Arquitetura e Urbanismo da Pontifícia Universidade Católica -

Puc-Rio - Rio de Janeiro Brasil

Ano 3 - N N $^{\circ}$ - ISSN 2446-7340 


\section{Processos didáticos na Cátedra Caruso}

Para compreender como estas imagens integram o processo de concepção na Cátedra Caruso será importante descrever os passos iniciais do percurso didático a partir de evidências empíricas, relatos e justificativas para as escolhas pedagógicas. A exposição a seguir se baseia em pesquisa realizada em 2013-14, referindo-se a processos didáticos levados a cabo no ano de 2013, mas que integram uma agenda pedagógica construída ao longo de anos.

\section{Pesquisa de Referências: Coleçôes}

Segundo Adam Caruso, o atelier adota uma abordagem descrita como "uma busca pela imagem do projeto", num percurso que é nitidamente "baseado em referências" [reference based]. O semestre é dividido em duas etapas: uma fase de pesquisa de referências e uma de concepção do projeto. A fase inicial consiste em investigar com profundidade uma série de precedentes arquitetônicos escolhidos pelos professores por sua pertinência em relação ao problema a ser enfrentado e por sua afinidade com a postura do atelier, constituindo uma coleçáo de soluçóes exemplares. A cada semestre uma coleção nova é montada, via de regra contendo edifícios de diferentes períodos da história. As análises privilegiam aspectos do problema de projeto que serão enfocados na fase de concepção. Tanto os discursos críticos sobre os projetos quanto os modos de representá-los enfocam tais aspectos.

Dois exemplos ajudarão a compreender. $\mathrm{O}$ tema do semestre da primavera de 2013 era a reforma dos edifícios da escola de arquitetura da ETH em Zurique. O mote foi a expressão Alles ist Umbau [tudo é remodelação/reforma], numa clara referência à noção de que a arquitetura sempre reconfigura um contexto pré-existente. Os projetos deveriam se concentrar principalmente nos espaços internos preservando as estruturas existentes. A questão mais importante era definir arranjos espaciais internos e estabelecer o caráter e atmosferas adequados para os distintos ambientes. A coleção de referências trazia projetos de remodelação e ampliação de estruturas existentes

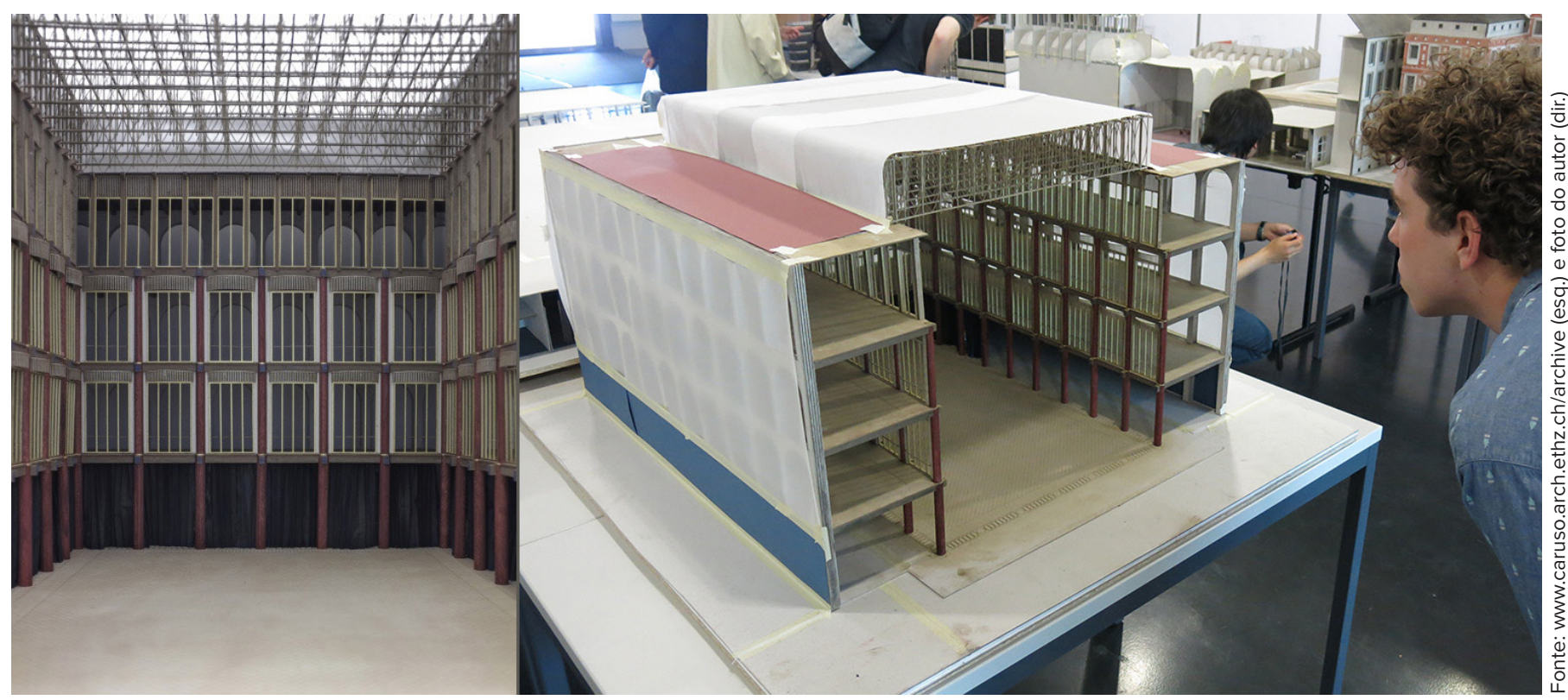

Figuras 09 e 10: Fotografia de modelos físicos (esquerda) e modelo que deu origem à imagem (direita). Projeto da Cátedra Adam Caruso, semestre de primavera de 2013. Tema: Alles ist Umbau. 


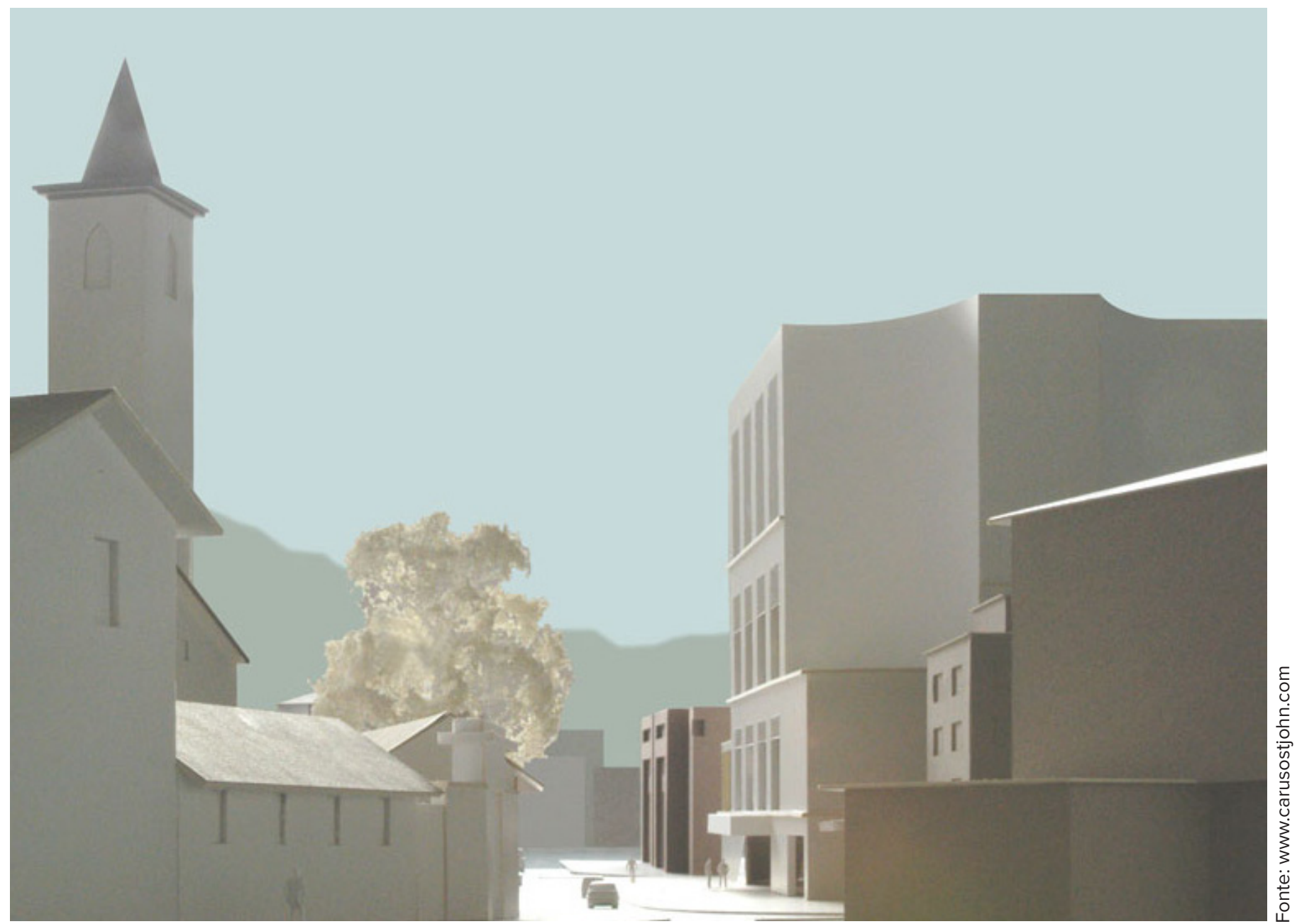

Figura 11: Fotografia de modelo físico. Projeto para Centro Turistico e Cultural em Ascona, Suiça, 2004.

que incluía tanto exemplares de importância histórica quanto arquiteturas mais ordinárias. As análises permitiram conhecer o dimensionamento e ordenação espacial, mapear as ampliaçôes, transformaçóes e mudanças nos usos ao longo dos anos. A coleção abriu espaço para a compreensão da não associaçáo necessária entre uso e organizaçáo espacial, numa clara referência à crítica ao funcionalismo ingênuo de Aldo Rossi (1966). Além disso, permitiu debater as relaçóes entre diferentes definiçóes de projeto - dimensionamento, tipos de relações entre espaços contíguos, aberturas e entradas de luz, revestimentos e acabamentos - e a produção da atmosfera e o caráter dos espaços internos. Para abordar este último tema, como veremos, foi fundamental o uso de imagens fotográficas.

No semestre de outono de 2013 o tema foi a construção de um conjunto de edifícios de uso coletivo em vazios urbanos no centro de Zurique. O mote do exercício era Metropolis. Com o objetivo de intensificar a urbanidade no centro da cidade, os projetos deveriam promover densificação e construir espaços capazes de abrigar programas de uso misto, além de prover uma imagem adequada, que garantisse aos edifícios um caráter condizente com o de uma metrópole. A coleção de referências incluía projetos históricos de densifica- 
ção ou expansão urbana, sempre relacionados a um período determinado: os arranha-céus de Louis Sullivan na Chicago do final do século XIX; os projetos de habitação coletiva de Berlage em Amsterdam de 1910 a 1940; o lote Haussmaniano na Paris da segunda metade do século XIX.

A seleçáo claramente ia ao encontro de interesses evocados por Adam Caruso, como a capacidade de congregar a preocupação com aspectos pragmáticos - como a racionalidade estrutural - com a busca por uma imagem com caráter adequado, isto é, uma expressão visual que estabelecesse continuidades culturais através de signos apropriados para uma arquitetura urbana: solidez, durabilidade, nobreza, racionalidade construtiva, economia.

\section{Pesquisa de Referências: Representaçóes}

O estudo das referências também envolvia refazer representaçóes dos projetos através de desenhos, modelos e imagens. Os desenhos incluíam plantas, cortes e fachadas realizados com precisão, em certos casos incluindo os detalhes construtivos. Através deles eram abordadas questôes relativas aos meios construtivos, à organização formal/espacial e à relação entre espaços e estrutura. Entretanto, são as imagens fotográficas que interessa examinar aqui com maior atenção.

No caso do projeto Alles ist Umbau - reforma da faculdade de arquitetura - a maioria das referências eram espaços existentes e acessíveis, o que permitiu aos estudantes visitar e perceber as qualidades ambientais diretamente, além de gerar fotografias que pudessem ser compartilhadas no atelier. A produção das imagens deveria seguir as convençôes do realismo descritivo da escola de Düsseldorf, referenciadas especialmente por Thomas Struth e Candida Höfer: planos abertos, grande profundidade focal, iluminação abundante, ausência de pessoas, composiçóes estáveis e centralizadas. Segundo Oliver Lütjens, professor assistente da cátedra, o privilégio dado ao registro objetivo tinha um propósito claro:

Nós precisamos saber o que há lá. Quais são as qualidades e os detalhes de um ambiente que o fazem ser o que ele é. Você nunca vai capturar a experiência com uma foto, mas consegue registrar certos detalhes, sabe? Texturas, acabamentos, cores. São coisas que estão na foto e que você nem lembra, mas que pode depois olhar com atenção e usar. Pode adaptar para o seu projeto ou buscar uma solução diferente que tenha a mesma qualidade. Queremos saber quais são os ingredientes que pedem fazer uma atmosfera.

Assim, mais do que simplesmente registrar a atmosfera e o caráter dos ambientes (o que talvez esteja de fato além do alcance da fotografia), se tratava de apresentar, de modo objetivo, o conjunto de fatores que, interligados, produziriam estas atmosferas: iluminação, acabamentos, escolha de mobiliário, altura dos ambientes, relações entre espaços adjacentes ou contíguos, posição da estrutura e sua relação com os elementos de definição espacial, etc.

$\mathrm{Na}$ coleção de referências do projeto Metropolis, por outro lado, os projetos não eram acessíveis. Assim, além de todos os desenhos, era preciso também produzir imagens. Para tanto os alunos realizaram mo- 
delos físicos obsessivamente detalhados que foram fotografados de pontos de vistas imersivos, seguindo o mesmo padráo que seria adotado nas apresentaçóes de projeto.

Limitados às fachadas, os modelos remetiam a cidades cenográficas. Isso não significava que a arquitetura fosse desprovida de fisicalidade. Ao contrário, os tratamentos das superfícies buscavam representar a aparência visual e a espessura da construção. A imagem possuía qualidades materiais que eram decorrência direta da corporeidade do modelo. Assim, enquanto o desenho fornecia uma descrição da anatomia técnico-construtiva do edifício, a imagem fotográfica dava conta de explicitar os efeitos visuais. Colocadas lado a lado, estas representações permitiam vincular a realidade formal e construtiva do projeto à imagem da arquitetura.

As imagens, contudo, não conseguiam (e não parece ser este o objetivo) ocultar sua artificialidade. Segundo Caruso (2015), os estudantes "constroem uma realidade particular com as imagens, que já não está ligada à realidade do edifício estudado". São representaçôes ficcionais que alimentam a imaginação com uma complexidade de elementos realistas que podem suscitar a evocação de experiências vividas. Segundo Lutiens, a escolha deste modo de representação se deve principalmente por permitir "realmente penetrar na sua realidade, que é a realidade do modelo".

Ao fim da etapa de pesquisa, que durou de duas a três semanas, os resultados foram apresentados e compilados em um livro que foi compartilhado com toda a turma gerando um acervo comum de desenhos, imagens, informaçôes e narrativas sobre um universo de referências pertinente ao problema de projeto e legitimado pelo crivo da cátedra. Segundo Caruso (2015):

O estudo de projetos de referência é uma maneira de construir uma espécie de cultura dentro do estúdio, sobre as coisas que estamos trabalhando, sobre os temas que gostaríamos de discutir, sobre os critérios que usaremos para julgar se um projeto é apropriado ou potente em seu lugar.

\section{Concepção do projeto: A imagem como sintese prévia}

$\mathrm{Na}$ segunda etapa do semestre, uma vez explicitadas as condicionantes objetivas do problema, se inicia sem demora o processo de concepção. Conforme descreve Oliver Lütjens:

Nós damos a eles uma semana, e então eles devem entregar uma fotografia de um modelo do seu projeto. Com Alles ist Umbau foi uma imagem de um interior, e agora com Metropolis foi um exterior. Em uma semana! Eles trabalham mais ou menos sem pensar. E nós dizemos, veja, você não precisa usar as referências, mas elas serão muito úteis se você quiser usá-las. Eles todos terminam usando.

As imagens produzidas nesta primeira etapa seguiam o padrão das fotografias de modelos usadas no exercício de análise: verossímeis, detalhadas, apresentando um conjunto de diferentes materiais. ( $\mathrm{O}$ uso da cortadora a laser aqui é crucial, pois possibilita realizar modelos precisos com rapidez). As imagens deveriam conter definições que normalmente são vistas apenas em etapas avançadas da concepção. Como indica 
Lutiens, a coleção de referências era um recurso importante para enfrentar o desafio: para compor a sua imagem o estudante empregava outras imagens. Ele se via em posiçáo de selecionar, combinar e adaptar as referências para formar uma imagem nova, pertinente a uma situação específica.

Este início é imediato. É muito intuitivo. $\mathrm{O}$ estudante não tem tempo de ponderar e experimentar muitas ideias. Nós cremos que ele escolhe entre as referências, imagens que o toquem por algum motivo. Esta busca é guiada por algum desejo dele, alguma curiosidade que ele não sabe exatamente o que é. Depois haverá tempo para ajustar e descobrir se são escolhas adequadas, mas com isso ele termina afirmando o desejo de ir em determinada direção.

Segundo Caruso (2015), o que interessa nesta escolha é principalmente o "conteúdo emocional das imagens". Ela está ligada aos efeitos que o estudante quer produzir, e é supostamente em função de como estes efeitos os atingem que eles fazem a escolha de suas referências. Quando questionado sobre o que se espera que as imagens mostrem, o assistente Murat Ekinci, foi categórico: "elas servem para acessar atmosferas."

Os estudantes já possuíam conhecimentos suficientes para saber que suas imagens deviam exibir soluçóes passíveis de serem desenvolvidas. O compromisso com as referências contribuía neste sentido, pois tratavam-se de projetos reais e que carregavam soluçóes arquitetônicas para diferentes aspectos do problema de concepção. A interpretação proposta aqui é que as imagens dos modelos operam como sínteses prévias, justamente por que carregam toda uma gama de soluçôes e significados arquitetônicos em uma única representação. Uma fachada, por exemplo, traz implícita também uma solução que pode ser o embriáo do sistema estrutural de todo conjunto. Do mesmo modo ela aponta para encaminhamentos sobre a definição de materiais, para interface com o espaço público, para a entrada de luz, etc. A imagem de um ambiente interno, por sua vez, aponta para relaçóes espaciais entre ambientes, meios de iluminação natural, interfaces entre espaço interior e exterior, etc. Mesmo que o estudante não seja plenamente consciente destas possibilidades, ele poderá explorá-las no desenvolvimento do projeto, etapa em que a direção do projeto já terá sido estabelecida em função da escolha de uma determinada atmosfera e de uma determinada referência arquitetônica.

\section{Concepção do projeto: fala agregando sentidos}

Tradicionalmente a fotografia do modelo domina a apresentação inicial na Cátedra Caruso. Mesmo que desenhos ou outros modelos mais esquemáticos tenham sido empregados para realizá-la - e isso de fato ocorre - eles não são exibidos. Uma única imagem impressa em grande formato é exposta na parede para avaliação crítica coletiva, onde é examinada com atenção e debatida extensamente. $\mathrm{O}$ atravessamento dos discursos sobre as imagens contribui decisivamente para definir a postura adotada ao enfrentar o problema de projeto.

Como lembra Flusser (1983), a percepção das imagens (enquanto representaçóes bidimensionais fixas) não se dá de modo linear. Ao contrário, elas se prestam a um olhar contemplativo que vaga sobre sua superfície seguindo sua estrutura, mas também a in- 


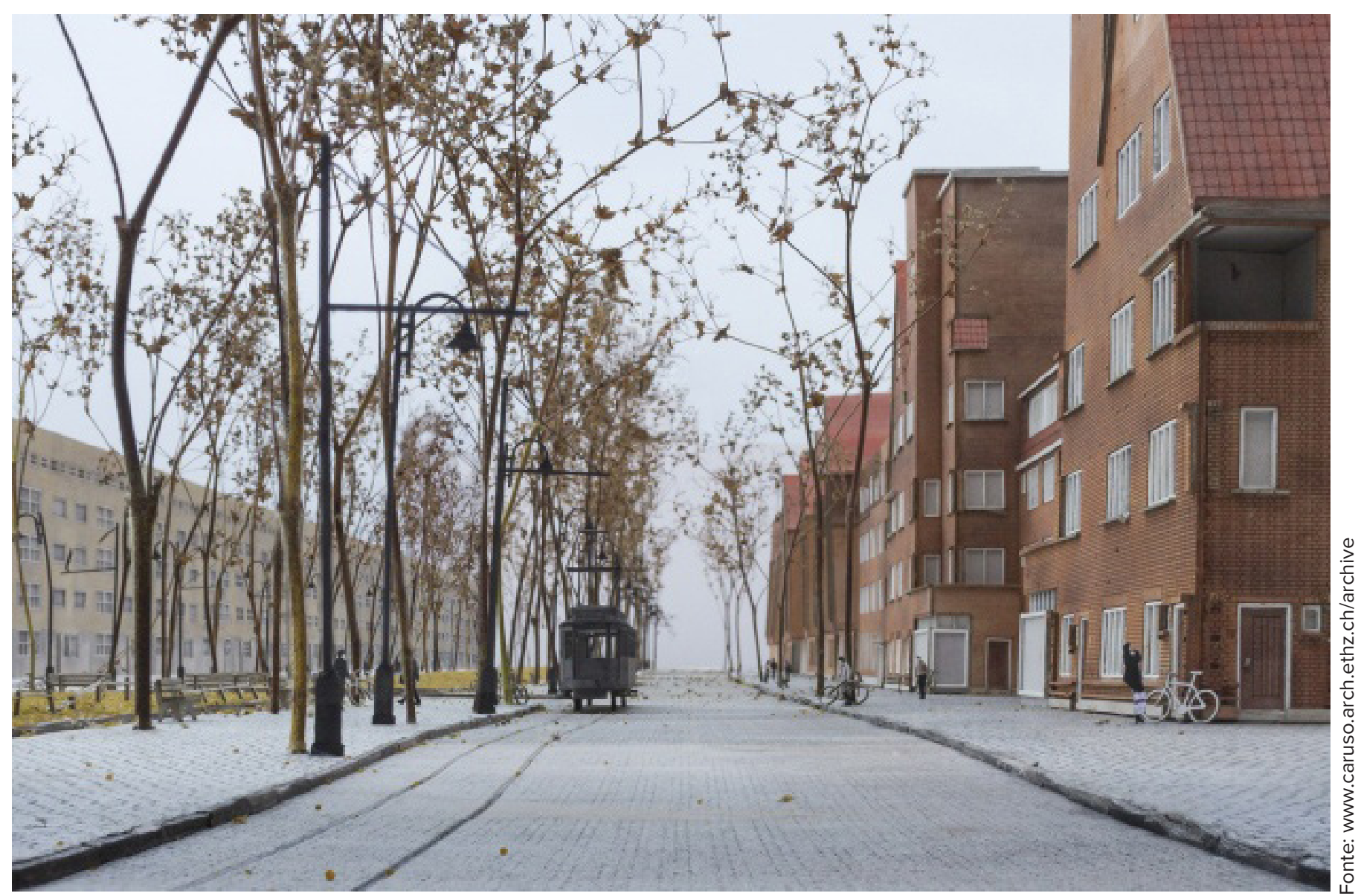

Figura 12: Pesquisa de referências na cátedra Adam Caruso. Fotografias de modelos físicos. Semestre de outono de 2013. Tema: Metropolis. Amsterdam 1900-1940.

tencionalidade do observador. Ainda que afetado pelos estímulos da imagem, o olhar é livre para deslizar sobre ela e eleger os elementos que serão portadores privilegiados da sua significação. Deste modo a percepção é capaz de ser guiada pela fala, o olhar é suscetível a sugestôes acerca de onde concentrar a atenção. Por serem conotativas elas oferecem um largo espaço interpretativo, sendo permeáveis a sugestóes de discursos que lhes agregam significados.

A interferência da fala é crucial para selar a vinculação das imagens com o enquadramento pretendido para o problema de projeto. Definir o que interessa ver nas imagens implica em assumir compromissos com determinados aspectos do projeto. Conforme coloca Oliver Lütjens, se a imagem permite que o estudante faça escolhas iniciais de projeto de modo mais intuitivo, ainda assim elas são passíveis de serem desenvolvidas.

$\mathrm{O}$ estudante não tem que assumir um compromisso estrito com esta primeira solução. Ela simplesmente faz as coisas andarem em uma determinada direção [get things going in a certain direction]. Eu diria que se há compromisso, não é 
com uma referência específica, mas com algo que ele viu naquela referência, um efeito, uma certa atmosfera. Isso pode ser inconsciente. E ele terá que nos convencer [aos professores] que este efeito é potente, é apropriado, vale ser explorado mais a fundo. Ele faz isso produzindo estes efeitos na imagem e nos mostrando como ele a entende e o que quer dela. Se a ideia for boa, então tentaremos ajudar a levá-la adiante, ajustando o projeto e preservando esta intenção inicial quando ele realizar os desenhos e trabalhar os outros aspectos do projeto. Às vezes ele não tem ideia de como fazer um edifício de tijolos, mas trouxe uma imagem potente inspirada em Fritz Höger, então ajudaremos a adaptá-la ao nosso tempo, à tecnologia do nosso tempo. É assim que funciona.

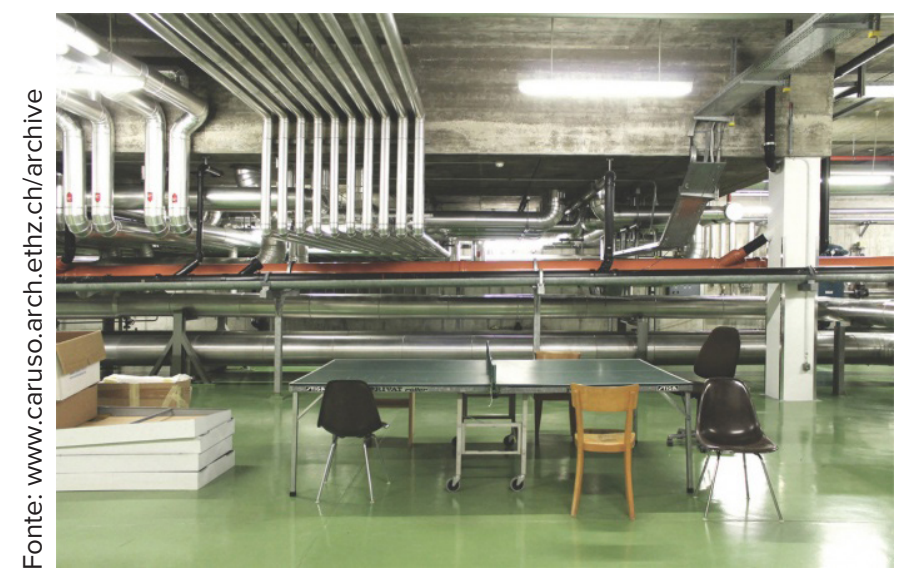

Figura 13: Fotografia do subsolo da atual sede da faculdade de arquitetura da ETH Zurique no campus de Honggerberg, Zurique. Foto dos estudantes para pesquisa de referências na Cátedra Adam Caruso, ETH Zurique, semestre de primavera de 2013. Tema: Alles ist Umbau [Tudo é Remodelação / Reforma].
Assim, o desenvolvimento subsequente do projeto passará a ser pautado, entre outras coisas, pela busca de meios para construir uma edificação que produza os efeitos trazidos na imagem desenvolvendo conhecimento sobre os recursos arquitetônicos necessários para este fim.

\section{Conclusão}

Se pretendeu demonstrar que nas práticas didáticas da Cátedra Caruso as imagens, em especial as fotografias de modelos, contribuem pra integrar certos valores arquitetônicos às posturas de concepção e que fazem isso controlando as qualidades específicas das representaçóes usadas no lançamento do projeto. Um conceito útil para compreender este processo é a antiga noção de "gerador primário", proposta por Jane Darke (1979). O gerador primário é uma soluçáo concisa - por vezes provisória - que coloca o processo em movimento atendendo apenas a determinados aspectos do problema de projeto. É um modo que o arquiteto tem de estabelecer compromisso com certos temas que ele escolhe valorizar, pois, se as primeiras conjecturas forem aceitas, os movimentos subsequentes tenderão a estar condicionados às soluçôes fixadas nestes esquemas iniciais. A contribuição de Darke está principalmente em evidenciar que a escolha dos aspectos a serem priorizados pelo gerador primário tem um caráter arbitrário, isto é, responde a desejos e valores dos arquitetos, como se escolhessem que problema de projeto querem resolver.

As imagens usadas para conceber o projeto nas fases iniciais na Cátedra Caruso operam como os geradores primários da concepçáo. Por terem mais ou menos as mesmas características, elas definem um campo relativamente restrito de questôes de projeto com as quais os estudantes se confrontarão. $\mathrm{O}$ caráter arbitrário dessas sínteses prévias do projeto faz com que o processo avance de modo relativamente arbitrário, 
pois suas escolhas de projeto são intuitivas, mas se inscrevem dentro de um universo de questóes cujos limites são definidos pela coleção de referências e pelas qualidades buscadas nas imagens.

A peculiaridade desta operação é inverter uma sequência tradicionalmente adotada na concepção: percurso que normalmente vai do geral para o particular, ou mais especificamente, do esboço esquemático para versóes sucessivamente mais definidas e detalhadas do projeto. $\mathrm{O}$ emblema desta abordagem é o parti, ou partido, diagrama gráfico inicial usado na tradição da escola de belas artes francesa. Adam Caruso $^{4}$ se refere justamente ao parti ao afirmar que a estratégia de empregar imagens de modelos é uma alternativa à entrada no projeto através do esquema abstrato e que busca não protelar a visualização da aparência visual do projeto.

Quando eu estava na escola, no início dos anos 1980, havia um retorno do interesse pela Beaux-Arts e pela ideia do parti. Você fazia o parti através de muitos croquis, e tudo viria dele. E eu me lembro que era muito bom nisso. $\mathrm{O}$ curioso é que ao longo dos anos eu perdi qualquer interesse pela ideia do parti e também me tornei profundamente cético acerca do croqui do arquiteto (acho que há um número muito pequeno de arquitetos cujos croquis valem examinar). Eu não olho para os desenhos dos meus alunos. Eu digo: isso é assunto privado seu. Eu preciso ver algo que é tridimensional para poder falar sobre o projeto. [...] No escritório é uma constante construçáo de grandes modelos porque eles dão a ver a imagem do pro- jeto. Quando você se preocupa com par$t i$, você tem que achar o melhor partido para então prosseguir, e as vezes você perde três semanas fazendo isso. E com nossos estudantes - alguns podem não gostar porque nós somos brutais neste sentido - em um certo momento pedimos que em 24 horas façam um modelo na escala 1:50, por exemplo, e produzam uma imagem a partir dele. [...] Assim eles começam. Porque você tem que começar, e com algo que você possa ver e reconhecer como arquitetura.

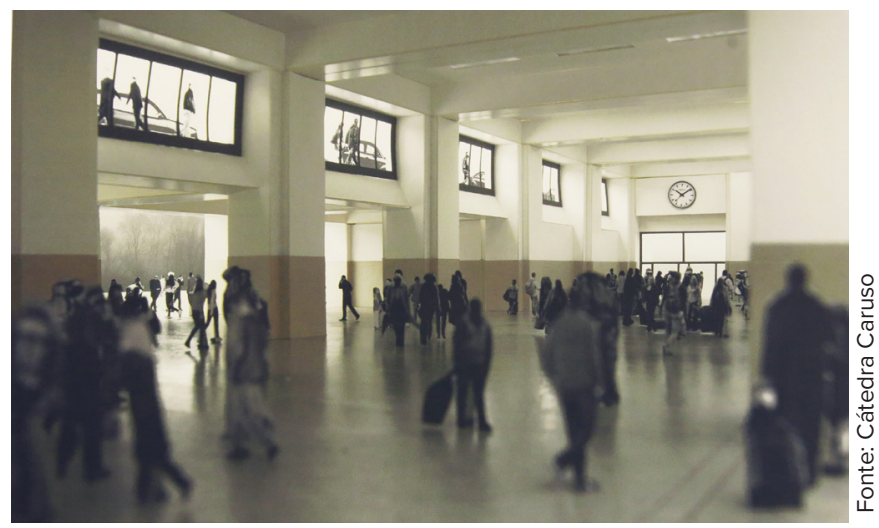

Figura 14: Imagem inicial de projeto no semestre de outono de 2013. Tema: Metropolis.

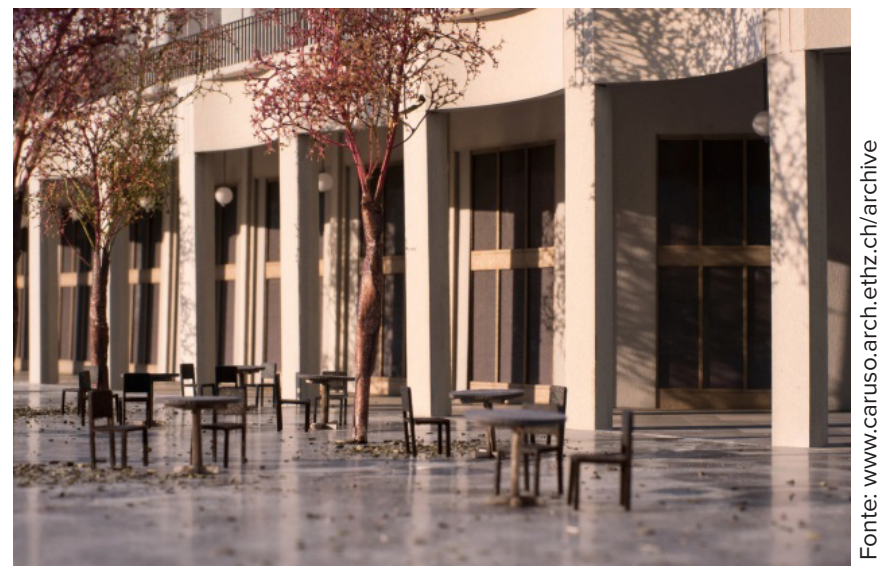

Figura 15: Imagem final de projetos da Cátedra Adam Caruso. Fotografias de modelos. Semestre de outono de 2013. Tema: Metropolis. 
O que Caruso descreve é uma prática que força uma tomada de posição por parte dos estudantes logo no início do projeto. Evitando protelar o enfrentamento de determinadas questóes que só chegariam mais tarde se o projeto fosse explorado apenas através de um diagrama abstrato. Aqui o compromisso inicial é com os efeitos visuais da arquitetura, assim como com toda uma gama de questôes envolvidas na produção destes efeitos.

Posto que a definição do modo de representação é uma prerrogativa dos professores, este termina sendo também um modo de inscrever o pensamento projetual dentro de um universo de problemas e de soluçóes para o projeto que são aceitáveis dentro do sistema de valores que compóem a agenda dos estúdios. $\mathrm{O}$ controle do modo de representação empregado nas primeiras conjecturas é, portanto, uma estratégia didática. Ela está baseada tanto na noção de que é possível controlar os geradores primários através dos modos de representação quanto na premissa de que pode haver uma conexão de sentidos entre um modo de representação e um sistema de valores arquitetônicos.
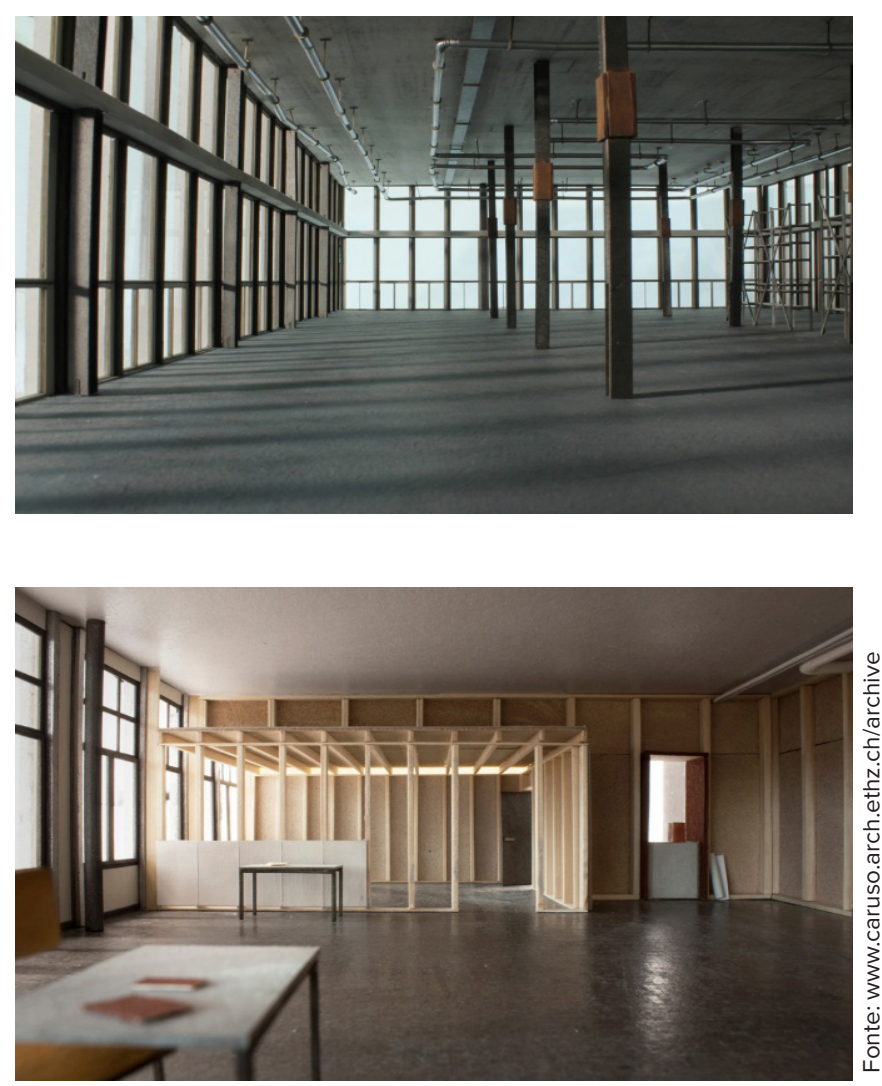

Figuras 16 e 17: Imagens finais de projetos da Cátedra Adam Caruso. Semestre de outono de 2013. Tema: Alles ist Umbau [Tudo é Remodelação / Reforma].

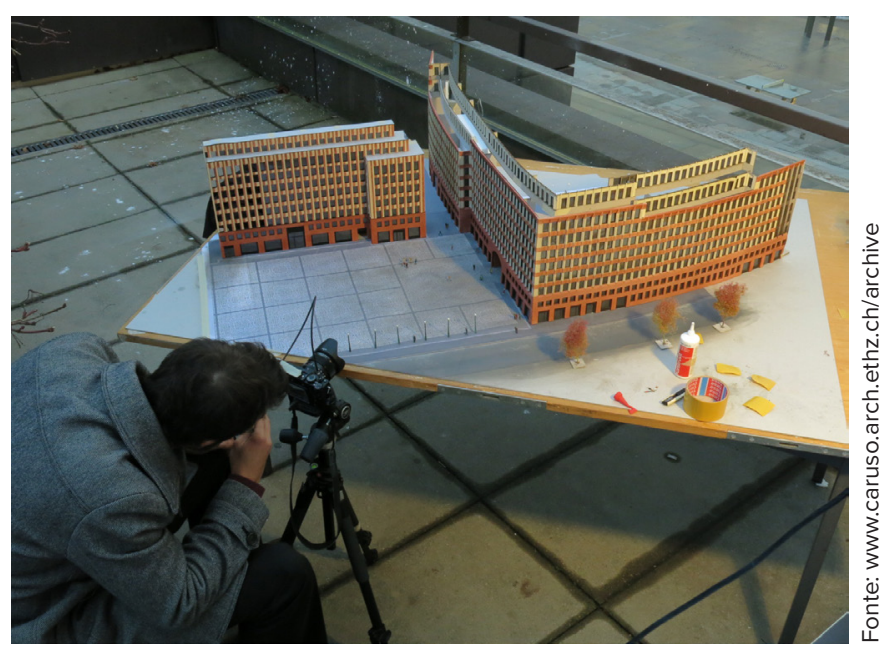

Figura 18: Elaboração de fotografias de modelos físicos por alunos da Cátedra Adam Caruso, ETH Zurique. 


\section{Notas de fim:}

1. As cátedras são unidades que comportam práticas de ensino e pesquisa, coordenadas por professores permanentes do quadro da ETH auxiliados por jovens arquitetos familiarizados com suas práticas.

2. Os artigos estão disponíveis no site do escritório www.

carusostjohn.com. Seus títulos são eloquentes acerca dos valores que promovem: Sigurd Lewerentz and a Material Basis for Form (1997a); The Tyranny of the New (1998); Traditions (2005) e The Feeling of Things (2008).

3. Um exame dos anuários da ETH, constante na tese de onde este artigo foi extraído, indica que desde os anos 1990 diversos professores empregaram fotografias de modelos em seus estúdios. Em entrevista com o autor em fevereiro de 2014, Mihail Amariei afirmou que Adam Caruso e Peter St John teriam reintroduzido esta a prática num formato semelhante ao empregado atualmente.

4. Esta fala foi apresentada em um debate promovido por Philip Urpsrung no Salon Suisse em Veneza durante a Bienal de Arquitetura de 2012 sobre o tópico da imagem na arquitetura. Participavam do debate, além de Caruso e Ursprung, Miroslav Šik, Barry Bergdoll, a fotógrafa Hélène Binet e Beatriz Colomina. <<https://vimeo. com/50075389 >>

\section{Referências Bibliográficas:}

BARAC, Matthew. (2011) Pedagogy: ETH Zurich, Switzerland. In: The Architectural Review [on-line] Postado em 31.10.2011. Acessado em 14.11.2011. < http:// www.architectural-review.com/essays/pedagogy-eth-zurich-switzerland/8621633.article>>

BARTHES, Roland. (1979) A Câmara Clara: Notas sobre a Fotografia. Rio de Janeiro: Nova Fronteira, 1984.

CARUSO, Adam. (1997a) Sigurd Lewerentz and a Material Basis for Form. In: OASE. Issue 45-46. Amsterdam: NAi Publishers. pp.88-95.

Shell, Cladding, Lining. (1997b) In: OASE. Issue 47. Amsterdam: NAi Publishers. pp.54-55.

(1998) The Tyranny of the New. Blueprint - Issue 150, pp. $24-25$.

(2005) Traditions. In: OASE. Issue 65. Amsterdam: NAi Publishers. nes Poligrafa.

(2008) The Feeling of Things. Barcelona: Edicio-

. (2009) Whatever Happened to Analogue Architecture. In: AA Files. Issue 59. London: Architectural Association School of Architecture.

(2015) The Fallacy of Modernism. Palestra proferida na Portland State University School of Architecture's 2014-2015 Lecture Series. [on-line] Postado em Fevereiro de 2015. Acessado em 12.03.2015. < https://vimeo. com/117992127 >>

DARKE, Jane. (1979) The primary generator and the design process. In: CROSS, N. (Ed.), Developments in Design Methodology. Chichester: J. Wiley \& Sons, 1984, p. 175-188. (Orig. In: Design Studies, n. 1).

DAVIDOVICI, Irina. (2012) Forms of Practice. German Swiss Architecture 1980-2000. Zurich, GTA Verlag.

DERIU, Davide. (2012) Transforming Ideas into Pictures: Model Photography and Modern Architecture. In: HIGGOT, Andrew; WRAY, Tim. (org.) Camera constructs: photography, architecture and the modern city. London: Ashgate.

FLORIS, Job. TEEDS, Hans. [2011]. On Models and Images. An Interview with Adam Caruso. In: Journal for Architecture OASE \#84 - Models. NAi Publishers. Rotterdam. Netherlands, 2011.

FLUSSER, Vilém. (1983) Filosofia da Caixa-Preta: ensaios para uma futura filosofia da fotografia. Tradução do autor. Rio de Janeiro: Relume Dumará, 2002.

FORTY, Adrian. (2000) Words and buildings. New York: Thames and Hudson.

LUCAN, Jacques. (2001) Architecture Analogue. In: Matiére D'Art: Architecture Contemporaine en Suisse. ITHA (Institut de Théorie et d'Histoire de l'Architecture). pp. 44-51. Basel: Birkhauser.

MALLGRAVE, Harry Francis. (1989) Introduction to the Four Elementos of Architecture. In: "The Four Elements of Architecture and Other Writings". Translated by: Harry Francis Mallgrave \& Wolfgang Herrmann. Cambridge University Press. 
MILLER, Quintus. (2013) Entretien avec Françoise Arnold. In: ARNOLD, Fronçoise. L'hypothèse Aldo Rossi. Les Productions du Effa.

MORAVANSZKY, Akós. (2007) Concrete Constructs. In: Architectural Design, n 189, Rationalist Traces, Setembro 2007, Wiley-Academy.

(2013) My Blue Heaven: The Architecture of Atmospheres. In: AA Files 61, London, AA publications.

ROSSI, Aldo. (1966) A Arquitetura da Cidade. São Paulo: Martins Fontes, 1982.

(1976) Uma Arquitetura Analógica. In: NESBITT, Kate. Uma Nova agenda para a Arquitetura: antologia teórica (1965-1995). São Paulo: Cosac Naify, 2006.

çóes $70,2013$.

(1981) Autobriografia Cientifica. São Paulo: Edi-

SACHER, Rolf. (2012) A Short History of Architectural Model Photography. In: ELSER, Oliver; SCHMAL, Peter Cachola. (Ed.) "The Architecture Model - Tool, Fetish, Utopia. Exhibition Catalog." Zurich: Scheidegger \& Spiess.

ŠIK, Miroslav. (1987) Analoge Architektur. Zurich: Edition Boga.

(1998) Binding Conflicts. Interview with Miroslav Šik. In: Daidalos no. 68 - Constructing Atmospheres. pp. 90-101.

(2013) Entretien avec Françoise Arnold. In: ARNOLD, Fronçoise. L'hypothèse Aldo Rossi. Les Productions du Effa.

STEINMANN, Martin. (1976) Reality as History: Notes for a Discussion or Realism in Architecture. In: HAYS, Michael. (Ed.) Architecture Theory since 1968. Columbia Books of Architecture, 2000. pp. 246-253.

(1982) Images. In: Forme Forte. Ecrits / Schriften 1997-2002. Basel: Birkhäuser.

(1989) Leçon des Choses. In: Forme Forte. Ecrits / Schriften 1972-2002. Basel: Birkhäuser.

(1991) Architecture récent en Suisse alemanique. In: Forme Forte. Ecrits / Schriften 1972-2002. Basel: Birkhäuser.

ZUMTHOR, Peter. (2006) Atmospheres. Basel:

Birkhäuser.

\section{Entrevistas:}

Adam Caruso, Catedrático, ETH Zurique (Maio 2013)

Murat Ekinci, assistente da Cátedra Caruso, ETH Zurique (Maio 2013)

Oliver Lütjens, assistente da Cátedra Caruso, ETH Zurique (Dezembro. 2013)

Mihail Armariei, assistente Atelier Bearth, Mendrísio (Fevereiro, 2014).

Revista online do Departamento de Arquitetura e Urbanismo da Pontifícia Universidade Católica -

Puc-Rio - Rio de Janeiro Brasil

Ano $3-N^{\circ} 5$ - ISSN 2446-7340 